\title{
The Doctrine of Illegality: A Private Law Hydra
}

\author{
Associate Professor James Goudkamp*
}

\section{Introduction}

At the beginning of the twenty-first century, the Law Commission embarked on a marathon investigation of the illegality doctrine. ${ }^{1}$ Its examination lasted more than a decade. While the Law Commission's attention initially was confined to the law of contract and trusts, the Law Commission ended up examining the illegality doctrine as it applies throughout the whole of private law. ${ }^{2}$ Eventually, the Law Commission's study was, in effect, aborted. In its final report, the Law Commission stated that the courts had brought (or were bringing) the law into a satisfactory state and that statutory intervention was hence unnecessary. ${ }^{3}$ In the Law Commission's words, 'The recent case law shows that the courts have become more open in explaining the policy reasons behind the illegality defence. Therefore, in most areas of law, we think that the illegality defence should be left to developments in the common law'. ${ }^{4}$ The Law Commission added: 'In view

\footnotetext{
Fellow, Keble College, Oxford; Associate Professor, Oxford Law Faculty; Academic Fellow, Inner Temple; Senior Honorary Research Fellow, Faculty of Law, University of Western Australia; Honorary Principal Fellow, School of Law, University of Wollongong; barrister, 7 King's Bench Walk. I am grateful to Lorenz Mayr for his illuminating comments on a draft of this article.

1 This article speaks in terms of the 'illegality doctrine'. The language, while convenient, is not entirely apposite. For one thing, the doctrine is capable of being triggered by conduct that is not illegal (as discussed at the text accompanying nn 52-53, below). The word 'doctrine' has been selected in preference for the word 'defence'. The choice has been made because the rule concerned does not always function as a defence if that word is taken to mean a principle that prevents liability from arising even if all of the elements of the cause of action in which the claimant sues are satisfied. Not infrequently, the rule prevents the claimant from establishing the elements of his or her cause of action. See the text accompanying nn 77-81, below.

2 Law Commission, Illegal Transactions: The Effect of Illegality on Contracts and Trusts (Law Com CP No 154, 1999); Law Commission, The Illegality Defence in Tort (Law Com CP No 160, 2001); Law Commission, The Illegality Defence: A Consultative Report (Law Com CP No 189, 2009); Law Commission, The Illegality Defence (Law Com No 320, 2010).

3 Law Commission (2010) (n 2) 50-51 [3.37]-[3.41].

4 Ibid vii [1.8].
} 
of these trends within the case law, we do not think that legislative reform is needed outside the area of trust law. ${ }^{5}$

Even without the benefit of hindsight, these remarks are surprising. Shortly before the Law Commission published its final report, the House of Lords delivered its judgment in Stone \& Rolls Ltd $v$ Moore Stephens. ${ }^{6}$ This appeal was concerned with whether the liquidators of a one-man company could recover damages from the company's auditor on account of its failure to detect and prevent frauds that the company perpetrated. A key issue was whether the action was barred for illegality (it was held that it was). This is not the place to engage with the decision in Stone \& Rolls. ${ }^{7}$ It suffices to say that the decision makes for immensely challenging reading. The speeches run to 277 paragraphs, not counting an annex on foreign law. All five Law Lords who heard the appeal delivered separate reasons. ${ }^{8}$ No clear principle emerges from the mêlée, which is something that the Law Commission itself noted. ${ }^{9}$ Lord Neuberger recently remarked that it is very hard to seek to derive much in the way of reliable principle from the decision' 10 in Stone \& Rolls. His Lordship added that it is not in the interests of the future clarity of the law for it to be treated as authoritative or of assistance [save in limited respects]' and that it should be 'put "on one side in a pile and marked 'not to be looked at again"'."11 In view of Stone \& Rolls, it is difficult to understand how the Law Commission managed to persuade itself that the common law concerning the illegality doctrine had worked (or was working) itself pure. If anything, the trend was in the opposite direction.

It is crystal clear that the law in this area has not undergone the coherent development that the Law Commission anticipated it would. If there is one point in respect of which there is widespread agreement regarding the illegality doctrine, it is that the relevant law is in far from a satisfactory state. Within a relatively short period of time after the Law

5 Ibid 51 [3.40].

6 [2009] UKHL 39, [2009] AC 1391 ('Stone \& Rolls').

7 For analysis, see Paul S Davies, 'Auditors' Liability: No Need to Detect Fraud?' (2009) 68 CLJ 505.

8 Lord Phillips, Lord Scott, Lord Walker, Lord Brown and Lord Mance.

9 '[T]there was no majority reasoning': Law Commission (2010) (n 2) 49 [3.32].

${ }^{10}$ Jetivia SA v Bilta (UK) Limited (in liquidation) [2015] UKSC 23, [2015] 2 WLR 1168 ('Bilta') [23]. Lord Sumption remarked that '[i]t is a difficult case to analyse' ([79]). Lord Toulson and Lord Hodge said "[c]ritics of Stone \& Rolls for being over long and diffuse have a fair point, and commentators and practitioners have found the case difficult' ([151]).

${ }^{11} \mathrm{Ibid}$ [30], quoting Lord Denning MR in In re King, deceased [1963] Ch 459 (CA) 483. 
Commission published its final report, the Supreme Court delivered three decisions concerned with the illegality doctrine. Those decisions were: Hounga $v$ Allen, ${ }^{12}$ Les Laboratoires Servier $v$ Apotex Inc ${ }^{13}$ and Jetivia SA $v$ Bilta (UK) Limited (in liquidation). ${ }^{14}$ The reasons given in these appeals do not take a consistent position in relation to the doctrine. In particular, the decision in Hounga is in considerable tension with that in Apotex. The distinct impression that the three cases create is that the Supreme Court's position on the subject of illegality depends largely on which Justices happen to constitute the Court in any given case. It is presumably for this reason that Lord Neuberger recently wrote: 'In my view, ... the proper approach to the defence of illegality needs to be addressed by this court (certainly with a panel of seven and conceivably with a panel of nine Justices) as soon as appropriately possible.... ${ }^{15}$ The Supreme Court has granted permission to appeal in a fourth case concerned with the illegality doctrine: Patel $v$ Mirza. ${ }^{16}$

The uncertainty that has been generated by this flurry of Supreme Court decisions prompted two of the Court's Justices, Lord Mance and Lord Sumption, to call extrajudicially for the Law Commission to re-examine the law of illegality. ${ }^{17}$ It is worth emphasising that these calls have come hot on the heels of the termination by the Law Commission of its study of the illegality doctrine on the basis that legislative reform was unnecessary. These judicial cries for help suggest the existence of a belief that the problems that have engulfed the law of illegality are so profound that the courts are ill-equipped to resolve them. In other words, the law in this area, as Diplock LJ put it in another context, may have "passed beyond redemption by the courts'. ${ }^{18}$ If the Law Commission reconsiders the law in this regard (there is no sign as yet that it is inclined to do so), the work probably would need to be conducted essentially de novo given the volume and importance of the jurisprudence that has emanated from the courts since the Law Commission's earlier investigation.

This article offers an analysis of the decisions in Hounga, Apotex and

\footnotetext{
${ }^{12}$ [2014] UKSC 47, [2014] ICR 847 ('Hounga').

${ }^{13}$ [2014] UKSC 55, [2015] AC 430 ('Apotex').

${ }^{14}$ Bilta (n 10).

${ }^{15}$ Ibid [15].

16 [2014] EWCA Civ 1047, [2015] Ch 271. Permission to appeal was granted on 15 December 2014.

${ }^{17}$ Jonathan Mance, 'Ex Turpi Causa - When Latin Avoids Liability' (2014) 18 Edinburgh LR 175, 192; Jonathan Sumption, 'Reflections on the Law of Illegality' (2012) 20 RLR 1, 8-12.

${ }^{18}$ Slim v Daily Telegraph Ltd [1968] 2 QB 157 (CA) 179.
} 
Bilta. ${ }^{19}$ It seeks to understand the reasons given in those cases and their implications. It will be argued that the law in this area poses, partly as a result of this trilogy of cases, significant threats to the rule of law. Consideration is given to how these threats should be headed off.

\section{Hounga}

In Hounga ${ }^{20}$ the Supreme Court unanimously held that a claimant who had been working in breach of immigration laws could recover damages from her employers (who were husband and wife) in the statutory tort of discrimination. A plea of illegality was rejected. The claimant in Hounga arrived as a child in the United Kingdom from Nigeria in 2007. Her eventual employers had fraudulently obtained a visitor's visa for her. Upon entering the United Kingdom, the claimant worked for the employers as 'a sort of au pair'. The claimant never had the right to work in the United Kingdom and she remained in the country after her visa had expired. The claimant eventually was dismissed from her employment (the conditions of which were highly exploitative and abusive) whereupon she sought relief in various causes of action. These actions included a claim in the statutory tort of discrimination, ${ }^{21}$ and it was in relation to that claim that the illegality doctrine fell for consideration. The Employment Tribunal and Employment Appeal Tribunal ${ }^{22}$ found that the doctrine was inapplicable. The Court of Appeal unanimously disagreed. ${ }^{23}$ The claimant's appeal to the Supreme Court was allowed, with all of the Justices concluding that the illegality doctrine was not enlivened. The main opinion was given by Lord Wilson (with whom Baroness Hale and Lord Kerr agreed). Short reasons were given by Lord Hughes (with whom Lord Carnwath agreed).

${ }^{19}$ For other treatments of this trio, see Graham Virgo, 'The Defence of Illegality in Unjust Enrichment' in Andrew Dyson, James Goudkamp and Frederick Wilmot-Smith (eds), Defences in Unjust Enrichment (Hart Publishing 2015).

${ }^{20}$ For further discussion of Hounga, see James Goudkamp and Mimi Zou, 'The Defence of Illegality in Tort Law: Beyond Judicial Redemption?' (2015) 13 CLJ 13; Alan Bogg and Sarah Green, 'Rights are Not Just for the Virtuous: What Hounga Means for the Illegality Defence in the Discrimination Torts' (2015) 44 ILJ 101.

${ }^{21}$ Race Relations Act 1976, s 4(2)(c) (now s 39(2)(c) of the Equality Act 2010).

22 [2011] Eq LR 569.

23 [2012] EWCA Civ 609, [2012] IRLR 685 (Rimer LJ, Sir Scott Baker and Longmore LJ concurring). For critical comment, see Alan Bogg and Tonia Novitz, 'Illegality and Race Discrimination' (2013) 129 LQR 12. 
Numerous points of interest and importance emerge from Lord Wilson's opinion. First, his Lordship seemed to be attracted to the reliance test, or at least felt that the authorities required him to give it significant prominence. ${ }^{24}$ According to this test, the illegality doctrine will be triggered if the claimant's action is based on his or her illegal conduct. In other words, the claimant's action will fail if he or she pleads facts that disclose illegal conduct on her or her part (or needs to plead such facts in order to establish that all of the elements of the action are satisfied). The reliance test has usually been applied in cases involving contract law and equity, ${ }^{25}$ but Lord Wilson thought that it applied in the tort context too. His Lordship remarked that it "continues to carry maximum precedential authority'. ${ }^{26}$ Although Lord Wilson did not say so expressly, his Lordship must have considered, given the outcome of the case, that the reliance test was unsatisfied, or that other considerations meant that even if it was satisfied, the illegality doctrine was nevertheless inapplicable.

Secondly, Lord Wilson doubted the utility of the approach to the illegality doctrine that had been propounded by Lord Hoffmann in his influential speech in Gray $v$ Thames Trains Ltd, ${ }^{27}$ judgment in which had been delivered not long beforehand. In Gray, a negligence case, Lord Hoffmann shunned the well-known 'inextricable link test' ${ }^{28}$ and suggested that the illegality doctrine's application instead should be determined by asking whether the claimant had by his or her own illegal act caused the damage about which he or she complained. ${ }^{29}$ If the claimant had brought about his or her own damage, recovery would be denied. This causal approach subsequently was adopted on several occasions by the Court of Appeal..$^{30}$ In

${ }^{24}$ The fons et origo of the reliance test is often considered to be Bowmakers Ltd $v$ Barnet Instruments Ltd [1945] KB 65 (CA).

${ }^{25}$ See, most notably, Tinsley $v$ Milligan [1994] 1 AC 340 (HL).

${ }^{26}$ Hounga (n 12) [30].

27 [2009] UKHL 33, [2009] AC 1339. For engagement with Lord Hoffmann's speech in Gray, see James Goudkamp, 'A Long, Hard Look at Gray v Thames Trains Ltd' in Paul S Davies and Justine Pila (eds), The Jurisprudence of Lord Hoffmann: A Festschrift in Honour of Lord Leonard Hoffmann (Hart Publishing 2015).

${ }^{28}$ The inextricable link test originated, it seems, in Cross v Kirkby [2000] EWCA Civ 426, Times, April 5, 2000. For cases addressing it, see e.g. Saunders v Edwards [1987] 1 WLR 1116 (CA) 1134; Hall v Woolston Hall Leisure Ltd [2000] EWCA Civ 170, [2001] ICR 99 [79].

${ }^{29}$ Gray (n 27) [54].

${ }^{30}$ See e.g. Delaney $v$ Pickett [2011] EWCA Civ 1532, [2012] 1 WLR 2149; Joyce $v$ O'Brien [2013] EWCA Civ 546, [2014] 1 WLR 70; cf McCracken v Smith [2015] EWCA Civ 380 [51] (Richards LJ, Underhill and Christopher Clarke LJJ agreeing). 
Hounga Lord Wilson suggested that this causal inquiry was no more likely than the inextricable link test 'to secure consistency in decision-making.' ${ }^{11}$ His Lordship did not indicate, however, why he was of this view.

Thirdly, Lord Wilson concluded that the inextricable link test was unsatisfied on the facts in Hounga. The claimant's illegality was said to be simply part of the 'context' in which the employers' wrongs were committed. ${ }^{32}$ It is uncertain why, precisely, his Lordship arrived at this conclusion. Lord Wilson appeared to place weight in this regard on the fact that the claimant and the employers were not 'equal participants in entry into the illegal contract. ${ }^{33}$ Lord Wilson then stated that 'the bigger question' than that of whether the inextricable test was satisfied was 'whether the ... test is applicable'. ${ }^{34}$ Rather remarkably, however, his Lordship did not answer (or even purport to answer) that question, with the result that it is uncertain whether or not he placed his decision at least partly on that test.

Fourthly, Lord Wilson thought that considerations of public policy were central to whether the illegality doctrine was enlivened. His Lordship concluded that considerations favouring the doctrine's operation in this case (such as the need to deter offending or to prevent wrongful profiting) were weak. Conversely, Lord Wilson identified two factors that militated, in his view, against its application. These factors were the risk that denying the claim might allow employers to discriminate against people such as the claimant with impunity, ${ }^{35}$ and the fact that the United Kingdom would be in breach of its international obligations with respect to combating human trafficking if recovery was not permitted in a case such as the present. ${ }^{36}$ These considerations clearly played a decisive role in Lord Wilson's conclusion that the claimant's appeal should be allowed.

In his short opinion, Lord Hughes decided the appeal on the basis of the inextricable link test. His Lordship concluded that there was not a sufficiently close connection between the illegality and the tort to bar [the] claim, ${ }^{37}$ As with Lord Wilson's reasons, it remains obscure

\footnotetext{
${ }^{31}$ Hounga (n 12) [36].

${ }^{32} \operatorname{Ibid}[40]$.

${ }^{33}$ Ibid [39].

${ }^{34}$ Ibid [41].

${ }_{35}^{35}$ Ibid [44(d)].

${ }^{36}$ Ibid [50].

${ }^{37}$ Ibid [59].
} 
why Lord Hughes reached this view or even what influenced him in this regard. A significant difference between Lord Wilson's reasons and those of Lord Hughes concerns policy. Whereas policy featured prominently in Lord Wilson's reasons, the same is not true of Lord Hughes' reasons. Lord Hughes did not discuss the policy factors that Lord Wilson had canvassed (or any other policy factors) beyond saying that he was unpersuaded that the United Kingdom's obligations regarding human trafficking provided 'a separate or additional reason' to exclude the doctrine. ${ }^{38}$ It is unclear what Lord Hughes' views were on the merits of a policy-based approach to the illegality doctrine more generally.

There is no doubt that the Supreme Court in Hounga was correct to conclude that the illegality doctrine was inapplicable. It was correct in this conclusion because denying the claim for illegality would not have accomplished anything worthwhile. Lord Wilson convincingly showed, for example, that it would be fanciful to think that rejecting the claim would deter people such as the claimant from committing the offences concerned. This does not mean, however, that the decision in Hounga is unproblematic. The Supreme Court's reasons suffer from at least four major problems. First, the Court left it unclear what test governs the illegality doctrine in discrimination claims and, probably, in private law generally. As observed, Lord Wilson (and hence a majority of the Justices) supported a test involving the balancing of policy considerations, but his Lordship also spoke with apparent approval of the reliance test. What is the relationship between these tests? Are they both potentially applicable? If they are, what happens where one supports recovery but another does not? Hounga offers no guidance on these pressing points.

The second difficulty concerns the fact that Hounga leaves the status of Gray unclear, which had been regarded as the leading authority on the illegality doctrine in negligence cases. As discussed above, ${ }^{39}$ Lord Wilson doubted the correctness of the causal approach that Lord Hoffmann had influentially developed in Gray. However, Lord Wilson did not say what rule he thought should apply instead in negligence claims. How should Gray be read in the light of Hounga? On the one hand, it is arguable that Hounga did not displace the principles established in Gray given that Hounga was not a negligence case and in view of the fact that Lord Wilson's remarks

\footnotetext{
${ }^{38}$ Ibid [67].

39 See the text accompanying $n$ 31, above.
} 
concerning Gray pertained to a peripheral part of his opinion. On the other hand, Lord Wilson plausibly can be interpreted as sending a firm message that the rules that had been adumbrated in Gray should be regarded as suspect. ${ }^{40}$ This reading of his Lordship's reasons leaves a lacuna in the law, as it means that they do not indicate what should fill the gap left by the displacement of the rules enunciated in Gray. Both of these ways of reading Lord Wilson's reasons in Hounga are open, and, as a result, it is extremely hard to say what the situation is in relation to the doctrine in (at least) the negligence context.

A third problem concerns the support that Lord Wilson lent to the reliance test. That test is unworkable in some cases and in others it renders the outcome hostage to luck. Whether or not a given fact that discloses illegality on the part of the claimant needs to be relied upon by the claimant depends on whether the fact concerned is constitutive of the claimant's cause of action. If it is part of the action, the claimant, by virtue of the rule that the claimant must plead and prove facts that show that the elements of his or her action are present, will be required to rely on it. The situation is otherwise if the fact concerned does not pertain to one of the elements of the claimant's action, and relates instead to whether a defence is enlivened. A formidable difficulty with the reliance test is that the courts have often not clearly indicated (or at all) whether a given issue forms part of the claimant's action or is a defence. ${ }^{41}$ In such cases, it is often impossible to know whether the claimant needs to rely on his or her illegality and, hence, the reliance test is unworkable. Another problem is that the courts do not have a coherent theory (or, indeed, any theory) as to when a particular issue forms part of the claimant's cause of action or is a defence. ${ }^{42}$ Frequently, issues are allocated as between these categories apparently at random or as a result of historical accidents. When this happens, the outcomes produced by the reliance test are entirely a matter of luck. The difficulties with the

${ }_{40}$ Cf AB v Chief Constable of X Constabulary [2015] EWHC 13 (QB), [2015] IRLR 284 [23] where Males J wrote that 'there is nothing in Hounga to suggest that Gray should be regarded as wrongly decided or that its essential reasoning is flawed.'

${ }^{41}$ Numerous illustrations of the difficulties that frequently are encountered in endeavouring to determine the allocation of any given particular issue as between the cause of action and defence categories are given in James Goudkamp, Tort Law Defences (Hart Publishing, 2013). To give one example, consider whether non-consent is part of the cause of action in the trespass torts or whether consent is a defence: ibid 65-68; White $v$ Johnston [2015] NSWCA 18, (2015) 87 NSWLR 779 [94]-[130] (Leeming JA).

${ }^{42}$ For discussion, see Goudkamp (n 41) ch 2, especially at 44-45. 
reliance test do not end with its being either unworkable or insensitive to the merits of the case. More fundamentally, no reason has ever been given (and certainly no convincing reason) why it should matter that the claimant needs to rely on his or her own illegality. Simply to assert (as the courts often have) that claimants cannot succeed where they need to rely on their own criminal act is, of course, no justification whatsoever for the reliance test. Such assertions are nothing more than a bald restatement of the reliance rule itself. The reliance test, in the context of the tort of statutory discrimination and beyond, should be condemned. It is worth noting that the reliance test finds little support in other jurisdictions. The High Court of Australia properly rejected it in its landmark decision in Nelson v Nelson. ${ }^{43}$ It has no hold on the law in Canada. ${ }^{44}$

The fourth concern relates to the inextricable link test. As discussed, Lord Hughes supported this test while Lord Wilson did not indicate what his position was in relation to it. The inextricable link test should also be abandoned. One problem with it is that it is simply unclear what it involves. Does it entail an enquiry as to whether the claimant caused his or her own damage? Lord Wilson evidently thought that it was separate from a causal enquiry given that he compared these approaches. ${ }^{45}$ But if the inextricable link test is not just a causal test, what does it involve? No answer to this question was given in Hounga (and no satisfactory answer has been offered elsewhere). A further problem with the test is that it has never been explained (and certainly never convincingly explained) why it should matter whether the claimant's illegality was inextricably linked to the damage. Why should not the test be more demanding or less demanding? Again, the inextricable link test has not resonated with the courts in other major common law jurisdictions.

For the reasons that have been given, Hounga contains many regrettable and downright baffling remarks. Nevertheless, it is in an important respect a major step in the right direction. The strength of the decision lies in the fact that Lord Wilson asked whether any useful purpose would be served if the claim was denied for illegality. As discussed earlier, Lord Wilson considered several policy factors that he thought supported and militated against the application of the illegality doctrine in the instant case. ${ }^{46}$ In

\footnotetext{
${ }^{43}$ (1995) 184 CLR 538.

${ }^{44}$ Hall $v$ Hebert [1993] 2 SCR 159.

${ }^{45}$ See the text accompanying nn 28-34, above.

${ }^{46}$ See the text accompanying nn 35-36, above.
} 
proceeding in this way, Lord Wilson was on the right track. It is axiomatic that the law should not adopt rules that accomplish nothing worthwhile, which do not engage with the merits of the case at hand or which cause significant injustice to individual litigants. It might be thought hardly commendable that attention was paid to whether invoking the illegality doctrine to preclude liability would achieve anything useful. However, the fact of the matter is that it is rare for the courts (at least in the United Kingdom) to ask in any detail (if they ask at all) whether any advantages would be yielded by denying a given claim on the grounds of illegality. Instead, judges have tended to retreat into rules such as the reliance test that have nothing to do with the merits of claims and which are wielded with no attention being paid to whether denying recovery would yield any benefits. As the discussion that follows will show, the Justices of the Supreme Court have subsequently divided sharply over whether Lord Wilson was right to have proceeded in the manner in which he did.

\section{Apotex}

Apotex concerned a patent dispute. Servier had obtained an interim injunction restraining Apotex from importing and selling a pharmaceutical product subject to the usual undertaking as to damages. It subsequently was held that the patent on which Servier relied, although it had been infringed, was invalid. ${ }^{47}$ Accordingly, the injunction was discharged and Apotex sought damages pursuant to the undertaking. That claim was resisted by Servier, relevantly, on the ground that the active ingredient in the product would have been manufactured and formulated into tablets in Canada in breach of a Canadian patent. In short, Servier relied upon illegality in the form of a foreign law tort. The plea of illegality succeeded at first instance. ${ }^{48}$ An appeal to the Court of Appeal was unanimously allowed. ${ }^{49}$ An appeal to the Supreme Court was unanimously dismissed, with the result that the illegality doctrine was inapplicable. Reasons were delivered by Lord Sumption (with whom Lord Neuberger and Lord Clarke agreed), Lord Mance and Lord Toulson.

\footnotetext{
47 [2007] EWHC 1538 (Pat). An appeal against that decision was dismissed: [2008] EWCA Civ 445.

48 [2011] EWHC 730 (Pat).

${ }^{49}$ [2012] EWCA Civ 593, [2013] Bus LR 80 (Etherton LJ, Laws and Kitchin LJJ concurring).
} 
The gist of Lord Sumption's reasons can be stated within a short compass. His Lordship stressed that the illegality doctrine requires turpitude but that not all wrongdoing constitutes turpitude for the doctrine's purposes. What was needed to trigger the doctrine, Lord Sumption said, was an act that 'engage[s] the interests of the state or, as we would put it today, the public interest. ${ }^{50}$ Criminal conduct was turpitude (although his Lordship contemplated that trivial offending and the commission of strict liability offences may not $\mathrm{be}^{51}$ ). Sufficiently immoral behaviour ${ }^{52}$ and "quasi-criminal behaviour ${ }^{53}$ could also suffice. However, mere private wrongs, Lord Sumption stated, did not sufficiently engage the public interest. Thus, the bare infringement of a patent could not, therefore, enliven the illegality doctrine. Lord Sumption wrote: ${ }^{54}$

Torts (other than those of which dishonesty is an essential element), breaches of contract, statutory and other civil wrongs, offend against interests which are essentially private, not public. There is no reason in such a case for the law to withhold its ordinary remedies. The public interest is sufficiently served by the availability of a system of corrective justice to regulate their consequences as between the parties affected.

Lord Sumption also stressed two further points about the illegality doctrine, both of which he felt were supported by the House of Lords' decision in Tinsley $v$ Milligan. ${ }^{55}$ His Lordship wrote: '[f]irst, [the illegality doctrine] is a rule of law and not a mere discretionary power. Secondly, [the doctrine] is based on public policy, and not on the perceived balance of merits between the parties to any particular dispute. ${ }^{56}$ Lord Sumption thought that it was essential to keep these features regarding the illegality doctrine, which are perhaps largely different ways of expressing the same proposition, firmly in mind in order faithfully to apply the decision in

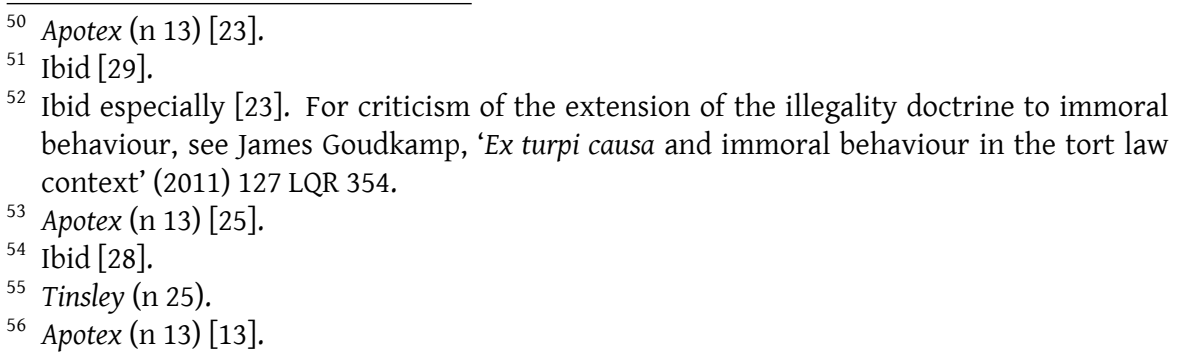


Tinsley. ${ }^{57}$ The conflict with Lord Wilson's approach in Hounga, which involves balancing the pros and cons of affording relief on the facts in that case, is both obvious and significant. Although Lord Sumption did not mention Hounga in his reasons, it seems clear that Lord Sumption considered that Hounga should be interred stillborn. ${ }^{58}$ It is important to note, however, that despite the considerable weight that Lord Sumption placed on these twin points, it is doubtful whether his remarks in this regard form part of the ratio of the Court's decision..$^{59}$ As has just been discussed, Lord Sumption disposed of the appeal on the basis that there was no turpitude. These two matters that his Lordship stressed seem to be entirely inessential to his reasoning in this regard.

Lord Mance and Lord Toulson agreed with Lord Sumption that the illegality doctrine was inapplicable. Lord Mance did so on the ground that there was no turpitude, apparently for the reasons offered by Lord Sumption. ${ }^{60}$ By contrast, Lord Toulson, in a brief opinion, emphasised the importance of looking at the competing policy considerations, ${ }^{61}$ and referred with ap-

${ }^{57}$ It is debatable whether Tinsley actually supports either of these two points. It is impractical to engage at length with Tinsley here. It is a confusing and confused decision. Briefly, however, only Lord Goff's speech (with which Lord Keith concurred) provides explicit support for the twin points concerned: Tinsley (n 25) 355, 358, 363-364. Lord Goff was hostile to a discretionary approach to the illegality doctrine and for that reason (among others) he rejected the public conscience test (that test is addressed at the text accompanying $\mathrm{n}$ 105, below). Lord Browne-Wilkinson, with whom Lord Jauncey and Lord Lowry agreed, indicated that he agreed with Lord Goff that the public conscience test should be rejected (at 367), but it is unclear whether Lord Browne-Wilkinson accepted Lord Goff's remarks regarding discretion.

${ }^{58}$ Lord Mance did not refer to Hounga either. Lord Toulson briefly mentioned it (Apotex (n 13) [61]-[62]). Presumably, Hounga did not feature more prominently in Apotex because argument in Apotex was heard several weeks before the decision in Hounga was delivered. A second likely reason why Hounga received little attention is that Hounga and Apotex were framed as being about different facets of the illegality doctrine: the question in Hounga was whether turpitudinous conduct was related to the claimant's action in the requisite way, while in Apotex the central issue was whether there was turpitude at all.

${ }^{59}$ A view shared by RA Buckley, 'Illegality in the Supreme Court' (2015) 131 LQR 341, 343.

60 Apotex (n 13) [34].

${ }^{61} \mathrm{Ibid}$ [46], [63]. It is interesting to observe that Lord Toulson felt comfortable embracing policy for the purposes of the illegality doctrine while in the recent decision in Michael $v$ Chief Constable of South Wales [2015] UKSC 2, [2015] 2 WLR 343 his Lordship was largely opposed to considering policy in relation to the duty of care element of the tort of negligence. For discussion of this aspect of Lord Toulson's reasons in Michael, see James Goudkamp, 'A Revolution in Duty of Care?' (2015) 131 LQR 519, 522. 
parent approval to the approach that Lord Wilson had adopted in Hounga. ${ }^{62}$ However, despite the weight that Lord Toulson placed on policy, he simply remarked that he could not 'see a good public policy reason' ${ }^{63}$ why the claim should be denied for illegality. Lord Toulson did not actually address any policy factors that supported or militating against the application of the illegality doctrine. With respect, this is unsatisfactory. It leaves the reader guessing as to the factors that Lord Toulson considered were relevant and irrelevant. It also leaves unknown the weight assigned to the the factors that were thought to be relevant.

Important remarks were made in Apotex concerning the purpose of the illegality doctrine. Lord Sumption considered that the doctrine exists in order to uphold the integrity of the judicial system. The doctrine serves this end, Lord Sumption thought, because it permits the courts to withhold relief where granting a remedy would ensnare the courts in an inconsistency. ${ }^{64}$ It would be inconsistent, Lord Sumption said, for the courts to condemn the claimant's turpitudinous conduct while simultaneously affording the claimant redress for loss sustained in the course of that conduct. This reasoning is highly problematic. Understanding the purpose of the illegality doctrine in this way leaves the fact that the doctrine extends (as Lord Sumption emphasised it did) to sufficiently immoral conduct unexplained. This is because it is, quite simply, no part of the courts' function to determine that given conduct is immoral or to condemn such conduct. Consequently, it is impossible for the principle of consistency to be engaged where the claimant has engaged in immoral conduct. Lord Sumption's rationale for the illegality doctrine does not justify the scope that he gave it. More seriously, Lord Sumption did not explain why (as he appeared to think) it generally would be inconsistent for the courts to compensate a wrongdoing claimant for loss that is sufficiently connected to turpitudinous conduct. It is hard to see any inconsistency in declaring a given claimant's conduct to be illegal and compensating the claimant in respect of loss suffered on account of a wrong committed against him. In compensating the claimant for loss, the court is not, for example, approving of the claimant's

\footnotetext{
${ }^{62} \operatorname{Apotex}$ (n 13) [61].

${ }^{63}$ Ibid [63].

${ }^{64}$ Ibid [24]. Lord Sumption wrote: 'In Lord Mansfield's day, and for some time thereafter, [the illegality doctrine] was sometimes expressed as a principle protecting the innocence or dignity of the court against defilement. ... Today, the same concept would be expressed in less self-indulgent terms as a principle of consistency.'
} 
wrongdoing. Nor would the courts, in undoing loss caused by a private law wrong, generally be restoring to the claimant anything that the criminal law might have taken away from him or her. Lord Sumption sought to draw support for his analysis in this regard from the celebrated opinion of McLachlin J in Hall v Hebert. ${ }^{65}$ However, as is well-known, McLachlin J had in mind a vastly narrower idea of inconsistency. Her Ladyship wrote: ${ }^{66}$

My own view is that courts should be allowed to bar recovery in tort on the ground of the plaintiff's immoral or illegal conduct only in very limited circumstances. The basis of this power, as I see it, lies in duty of the courts to preserve the integrity of the legal system, and is exercisable only where this concern is in issue. This concern is in issue where a damage award in a civil suit would, in effect, allow a person to profit from illegal or wrongful conduct, or would permit an evasion or rebate of a penalty prescribed by the criminal law. The idea common to these instances is that the law refuses to give by its right hand what it takes away by its left hand. It follows from this that, as a general rule, the ex turpi causa principle will not operate in tort to deny damages for personal injury, since tort suits will generally be based on a claim for compensation, and will not seek damages as profit for illegal or immoral acts.

As this passage reveals, McLachlin J's opinion offers no comfort at all to the notion that the principle of consistency supports withholding relief whenever the claimant suffered loss in the course of an illegal course of conduct.

A further point of importance in Apotex concerns Lord Sumption's claim that the illegality doctrine is a rule of law as opposed to a discretionary power. ${ }^{67}$ Lord Sumption made these remarks in response to the Law Commission's work on the topic of illegality and on account of the approach

65 Hall v Hebert (n 44).

66 Ibid 169 (emphasis added). For an account of developments in Canadian law in this regard since Hall was decided, see Beverley McLachlin, 'Weaving the Law's Seamless Web: Reflections on the Illegality Defence in Tort Law' in Andrew Dyson, James Goudkamp and Frederick Wilmot-Smith (eds), Defences in Tort (Hart Publishing, 2015).

67 See the text accompanying n 56, above. Lord Sumption's approach in this regard is supported in James Fisher, 'The ex turpi causa principle in Hounga and Servier' (2015) 78 MLR 854. 
taken by the courts below in Apotex. The Law Commission had provisionally proposed that the illegality doctrine should be governed by a 'structured discretion'. ${ }^{68}$ Lord Sumption felt that the Law Commission had erred in making this recommendation. It seems that his Lordship was of this view because he considered that, if implemented, this recommendation would have made the outcomes yielded by the law of illegality more unpredictable. ${ }^{69}$ Lord Sumption's reasoning appears to have been: (1) uncertainty in the law is in principle objectionable; (2) discretionary rules invite uncertainty to a greater extent than non-discretionary rules (which Lord Sumption calls 'rules of law'), all other things being equal; (3) therefore, the illegality doctrine should be governed by a rule of law. It is not possible to engage properly with the merits of either the 'structured discretion' postulated by the Law Commission ${ }^{70}$ or the strength of Lord Sumption's reasons for rejecting it (there is not enough space available in which to do so). Instead, two simple points will be made en passant. The first is that Lord Sumption's criticism of the Law Commission's recommendation perhaps commits him to the claim that there should be no discretionary rules in private law. That would be a very radical position to take. Adopting it would require a vast number of private law rules to be jettisoned. Discretionary rules are of course extremely widespread in private law. An excellent illustration of such a rule is the apportionment provision for contributory negligence. ${ }^{71}$ This provision, which is of immense practical significance, gives judges almost unfettered discretion to determine the amount by which a claimant who is guilty of contributory negligence should have his damages reduced..$^{72}$ The reduction

68 'We suggest that the current rules applied by the courts when considering the effect of illegality on a tortious claim should be replaced by a structured discretion, under which the court would be directed to consider whether, in the light of the underlying rationales and taking into account a number of guiding factors, the claim should be allowed or disallowed': Law Commission (2001) (n 2) 8 [1.18].

69 Apotex (n 13) [21].

${ }^{70}$ It is supported in Andrew Burrows, 'Alternatives to Legislation: Restatements and Judicial Law Reform' in Louise Gullifer and Stefan Vogenauer (eds), English and European Perspectives on Contract and Commercial Law: Essays in Honour of Hugh Beale (Hart Publishing 2014) 47-51; Paul S Davies, 'The Illegality Defence? Two Steps Forward, One Step Back?' [2009] Conv 182.

${ }^{71}$ Law Reform (Contributory Negligence) Act 1945, s 1.

${ }^{72}$ The highly discretionary nature of this rule is reflected in the fact that appeals in respect of its application will be allowed only exceptionally: Jackson $v$ Murray [2015] UKSC 5, [2015] 2 All ER 805 [27]-[38]. 
need only be 'just and equitable'. ${ }^{73}$ Additional examples include the doctrines of unclean hands and specific performance. Many other illustrations of highly discretionary rules in private law could be supplied without any difficulty. The second point is that is unclear whether a discretionary approach involving the balancing of relevant policy factors in individual cases really would be likely to lead to the unpredictability in outcomes that Lord Sumption fears, at least if the relevant (and irrelevant) factors are clearly identified and carefully defined. The experience in Canada is highly significant in this regard. Canadian courts, pursuant to Hall $v$ Hebert, ${ }^{74}$ take account of a host of policy considerations, such as whether granting a remedy would facilitate wrongful profiting (the Supreme Court of Canada indicated clearly that ordinarily it would not ${ }^{75}$ ). It does not seem that this approach has caused particular problems in Canada. On the contrary, the outcomes produced by the law in Canada following the seminal decision in Hall $v$ Hebert seem to be highly predictable. ${ }^{76}$

A final point of note in Apotex concerns the proper classification of the illegality doctrine within private law. Scholars and judges largely have failed to recognise that the doctrine prevents liability from arising in myriad conceptually distinct ways. ${ }^{77}$ Sometimes, it operates by attacking an element of the action in which the claimant sues. For example, on the approach endorsed in Gray, the doctrine works by stopping the element of causation of the tort in negligence from being satisfied. ${ }^{78}$ On other occasions, the doctrine functions as a defence; that is to say, it prevents liability from arising even if the cause of action in which the claimant sues is complete. ${ }^{79}$ It seems that Lord Sumption considers the doctrine to operate neither as a denial of an element of an action nor as a defence. His Lordship wrote that the doctrine 'although described as a defence, it is in reality a rule of judicial abstention'. ${ }^{80}$ This claim is important for it suggests that the

\footnotetext{
${ }^{73}$ For discussion of the role of discretion in relation to the apportionment provision, see James Goudkamp, 'Apportionment of Damages for Contributory Negligence: A Fixed or Discretionary Approach?' (2016) Legal Studies (forthcoming).

${ }^{74}$ Hall $v$ Hebert (n 44).

${ }^{75}$ See the quote set out at $\mathrm{n} 66$, above.

${ }^{76}$ This impression is conveyed by the Supreme Court of Canada in British Columbia v Zastowny [2008] SCC 4, [2008] 1 SCR 27.

${ }_{77}$ For discussion, see Goudkamp (n 41) 61-62, 71, 126-127.

${ }^{78}$ See the text accompanying $n 29$, above.

${ }^{79}$ See e.g. Cross $v$ Kirkby (n 28).

${ }^{80}$ Apotex (n 13) [23].
} 
private law universe may not be divisible, as is often thought, into a bipartite system that is comprised of actions and defences. ${ }^{81}$ If private law should be conceived of as containing a third category, what else, in addition to the illegality doctrine, should be placed into that category, if anything? This is an important question that goes to how the structure of private law should be conceptualised.

\section{Bilta}

The proceedings in Bilta arose as a result of an alleged VAT carousel fraud. Bilta (UK) Ltd had incurred, as a consequence of the purported fraud, a VAT liability in excess of $£ 38$ million. The company was compulsorily wound up pursuant to a petition presented by Her Majesty's Revenue and Customs. The liquidators brought proceedings in the usual array of actions against several of the company's directors who were said to be responsible for the asserted fraud. The liquidators also sued the appellants, who were alleged to have assisted and/or conspired with the directors. The appellants unsuccessfully applied to have the claim against them struck out on the basis of the illegality doctrine. ${ }^{82}$ Appeals to the Court of Appeal ${ }^{83}$ and to the Supreme Court were unanimously dismissed. In the Supreme Court, reasons were given by Lord Neuberger (with whom Lord Clarke and Lord Carnwath agreed), Lord Mance, Lord Sumption, and Lord Toulson and Lord Hodge.

The Supreme Court's reasons centre on when the wrongdoing of a company's directors is attributable to the company. Discussion of that aspect of Bilta is beyond the scope of this article. Briefly, however, the Court held that where a company had been the victim of a wrong committed by its directors, the directors' wrongdoing will not be attributed to the company. Consequently, their wrongdoing cannot be used to found a good answer to a claim brought by the company (or its liquidators) against the directors. This principle holds true even where the director sued is the sole director and shareholder of the company concerned.

\footnotetext{
${ }^{81}$ For further discussion of Lord Sumption's claim in this regard, see Andrew Dyson, James Goudkamp and Frederick Wilmot-Smith, 'Defences in Unjust Enrichment: Questions and Themes' in Andrew Dyson, James Goudkamp and Frederick Wilmot-Smith (eds), Defences in Tort (Hart Publishing, 2015) 1, 7-8.

82 [2012] EWHC 2163 (Ch), [2013] 2 WLR 825.

${ }^{83}$ [2013] EWCA Civ 968, [2014] Ch 52 (Patten LJ, Rimer LJ and Lord Dyson MR concurring).
} 
The Court did not engage extensively with the illegality doctrine. It did not hear full argument in relation to it. Lord Neuberger ${ }^{84}$ and Lord Mance ${ }^{85}$ thought that, in these circumstances, it would be inappropriate to address the doctrine and said little about it. More detailed but nevertheless brief remarks were offered by Lord Sumption and by Lord Toulson and Lord Hodge. Lord Sumption, while largely repeating what he had said about the law of illegality in Apotex, made several noteworthy remarks. His Lordship rejected the suggestion that it was permissible to consider a statutory policy in determining whether the illegality doctrine was applicable. ${ }^{86}$ The statutory policy in issue in Bilta was a policy that required directors to take account of the interests of creditors of an insolvent or prospectively insolvent company. ${ }^{87}$ Lord Sumption wrote: 'The fact the illegality defence is based on policy does not entitle a court to reassess the value or relevance of that policy on a case-by case basis. ${ }^{, 88}$ His Lordship added: 'Courts normally examine the policy rationale of a rule of law in order to discover what the rule is, not in order to decide whether they approve of its application in a particular case. ${ }^{89}$ Three points are worth noting at this juncture. First, it is most doubtful whether Lord Sumption's claim that the courts only infrequently consider whether the policy that supports a particular rule affects the rule's application in any given case is correct. Several of the best-known rules in private law involve essentially such an analysis. A good illustration is the Caparo ${ }^{90}$ test, which is used to ascertain whether a duty of care exists for the purposes of the tort of negligence. The third stage of that test - the 'fair, just and reasonable' stage - expressly requires the courts to weigh salient policy considerations that support and militate against the imposition of a duty of care. ${ }^{91}$ Secondly, even if Lord Sumption's claim in this connection is correct, it would

${ }^{84}$ Bilta (n 10) [16].

${ }^{85}$ Ibid [34].

${ }^{86}$ Ibid [98].

${ }^{87}$ Companies Act 2006, ss 172(3), 180(5).

${ }^{88}$ Bilta (n 10) [99].

${ }^{89}$ Ibid [101].

90 Caparo Industries plc v Dickman [1990] 2 AC 605 (HL).

${ }^{91}$ For a lengthy list of policy factors that judges have weighed in this regard, see Jane Stapleton, 'Duty of Care Factors: A Selection from the Judicial Menus' in Peter Cane and Jane Stapleton (eds), The Law of Obligations: Essays in Celebration of John Fleming (Clarendon Press, 1998). See also Edwin Peel and James Goudkamp, Winfield \& Jolowicz on Tort $\left(19^{\text {th }}\right.$ edn, Sweet \& Maxwell 2014) [5-031]-[5-035]. 
not explain why the courts should not determine the applicability of the illegality doctrine by weighing the relevant policy considerations on a case-by-case basis. Thirdly, it is most odd, given the supremacy of statutory law, that a common law rule should be insensitive to a policy manifested in a relevant statute. It is trite law that the common law must be developed in a way that is compatible with material statutes. ${ }^{92}$ It is worth noting that Lord Sumption's approach in this regard is diametrically opposed to the position taken by the High Court of Australia. In that jurisdiction, the application of the illegality doctrine depends principally on whether the statute that the claimant violated evinces an intention that he or she should be deprived of a remedy. ${ }^{93}$

Lord Sumption also contended that the decision in Hougna was compatible with his approach to the law of illegality. His Lordship argued that Hounga should not be understood as endorsing a discretionary approach to the illegality doctrine. The Court in Hounga, Lord Sumption said, had 'simply recognised the case before it as one in which a competing public policy required that damages should be available even to a person who was privy to her own trafficking. ${ }^{194}$ This reading of Hounga is untenable. As discussed earlier, ${ }^{95}$ Lord Wilson explicitly weighed several policy considerations that he thought bore upon the applicability of the illegality doctrine. The suggestion that Lord Wilson simply had in mind 'a competing public policy' is unsustainable. However, even if Lord Sumption's reading of Hounga was justified, it would not render it compatible with his approach to the illegality doctrine. This is because Hounga would still have involved recourse to policy to determine whether the doctrine should apply. According to Lord Sumption (and the other judges who agreed with him in Apotex), any consideration of policy with a view to determining whether the doctrine should apply in a given case is impermissible.

Lord Toulson and Lord Hodge proceeded very differently from Lord Sumption in relation to the illegality doctrine. They endorsed Lord Wilson's approach in Hounga. Their Lordships emphasised that Lord Wilson's policy

\footnotetext{
92 For discussion, see Andrew Burrows, 'The Relationship between Common Law and Statute in the Law of Obligations' (2012) 128 LQR 232.

${ }^{93}$ Nelson $v$ Nelson (1995) 184 CLR 538, 559; Fitzgerald v FJ Leonhardt Pty Ltd (1997) 189 CLR 215; Miller v Miller [2011] HCA 9, (2011) 242 CLR 446.

${ }^{94}$ Bilta (n 10) [102].

${ }^{95}$ See the text accompanying nn 35-36, above.
} 
analysis formed part of the ratio of the decision in Hounga. ${ }^{96}$ Lord Toulson and Lord Hodge also contended that it would be wrong for Apotex to be understood as rejecting Lord Wilson's policy analysis given: (1) that it was not explicitly stated in Apotex that the reasons given in Hounga were wrong; and (2) that Apotex was concerned with a very different facet of the law of illegality from Hounga. ${ }^{97}$ It is clear that Lord Toulson and Lord Hodge disagreed with Lord Sumption that the latter's views regarding the illegality doctrine could be squared with Lord Wilson's approach. For the reasons that have been given, they were correct to do so.

\section{What is the current law of illegality?}

This article has offered an analysis of the Supreme Court's decisions in Hounga, Apotex and Bilta. These cases comprise the totality of the Court's jurisprudence on the illegality doctrine to date. Any commentator who seeks to offer a statement of the law on illegality in light of these decisions could do so only with considerable trepidation. However, they probably can be regarded as establishing the following points. First, Lord Wilson's policy analysis in Hounga is relevant to the determination of whether the illegality doctrine applies in any given case. Strictly speaking, that analysis survived the decision in Apotex. It was part of the ratio of Hounga while Lord Sumption's remarks in Apotex that were critical of it were dicta. Secondly, the reliance test 'continues to carry maximum precedential authority', ${ }^{98}$ although its relationship with Lord Wilson's policy analysis is obscure. Thirdly, mere private law wrongs do not constitute turpitude and hence cannot enliven the illegality doctrine. Sufficiently immoral conduct can constitute turpitude, as can some quasi-criminal wrongs. Beyond this, much of the law of illegality remains unclear. It is plain that the courts' jurisprudence in this area is in a state of flux.

\section{The illegality doctrine and the rule of law}

Although various principles regarding the illegality doctrine can be extracted from Hounga, Apotex and Bilta, as discussed under the previous head-

\footnotetext{
${ }^{96}$ Bilta (n 10) [173].

${ }^{97}$ Ibid. See $\mathrm{n} 58$, above.

${ }^{98}$ Hounga (n 12) [30].
} 
ing, the doctrine poses a significant rule-of-law challenge to private law. The purpose of this section is to discuss three related ways in which the rule of law is threatened and to consider how these threats might be addressed. ${ }^{99}$

The first threat arises on account of the uncertainty that afflicts the law of illegality. Uncertainty is, of course, antithetical to the rule of law. If the law is uncertain, one cannot discover what one's legal position is. The illegality doctrine can be traced at least back to Lord Mansfield's celebrated remark in Holman $v$ Johnson that '[n]o Court will lend its aid to a man who founds his cause of action upon an immoral or an illegal act.' ${ }^{100}$ However, it is widely agreed that efforts to elaborate upon Lord Mansfield's principle have yielded a confusing mass of cases. Lord Sumption in Apotex remarked " $t]$ he question what is involved in "founding on an immoral or illegal act" has given rise to a large body of inconsistent authority which rarely rises to the level of general principle. ${ }^{101}$ In the same case, Lord Toulson said that Lord Mansfield's 'statement made in 1775 remains a succinct statement of broad principle, but, as the cases over the last 240 years demonstrate, it does not provide a simple measuring rod for determining the boundaries of the principle. The case law is notoriously untidy. ${ }^{102}$ What is needed, and needed urgently, is a clear statement of the law on illegality. Such a statement obviously could be either legislative or judicial in nature. Of course, the critical problem in this regard is the fact that there is no agreement as to what the law should be. This is not the place to engage with that issue, ${ }^{103}$ however, as doing so would divert attention to the focus of this section, which is to consider the interaction between the illegality doctrine and the rule of law.

Next, consider the fact that the law of illegality has undergone numerous and rapid changes. Each time a test for the application of the illegality doctrine is killed off, the law, Hydra-like, sprouts multiple additional tests to

\footnotetext{
99 The analysis in this section has been influenced by the classic study in LL Fuller, The Morality of Law (Yale UP, 1964) ch 2.

${ }^{100}$ (1775) 1 Cowp 341, 343; 98 ER 1120, 1121.

${ }^{101}$ Apotex (n 13) [14]. Lord Sumption also referred at [28] to the 'long and much-litigated history of the illegality defence'. In Bilta (n 10) [61] Lord Sumption wrote that Lord Mansfield's statement 'by the end of the 20th century ... had become encrusted with an incoherent mass of inconsistent authority.'

${ }^{102}$ Apotex (n 13) [57].

${ }^{103}$ For one opinion, see James Goudkamp, 'The Defence of Joint Illegal Enterprise' (2010) 34 MULR 425, 440-446.
} 
take its place. For some time, the 'public conscience' test prevailed. ${ }^{104}$ That test asked whether permitting recovery would, in view of the claimant's wrongdoing, shock the public. If the public's conscience would be affronted by an award of damages, recovery would be denied. That test was severed from private law by the House of Lords' decision in Tinsley v Milligan. ${ }^{105} \mathrm{Nu}-$ merous other tests sprung up to replace it or otherwise remained extant. These tests included the causal approach promoted in Gray, ${ }^{106}$ the reliance test, ${ }^{107}$ the inextricable link test, ${ }^{108}$ a test that asks whether denying recovery would be proportionate to the gravity of the claimant's wrongdoing ${ }^{109}$ and a test that looks to the legislative intention underpinning the statute that the claimant contravened. ${ }^{110}$ Cases in which the parties were engaged in a joint illegal enterprise were decided by asking whether the nature of the parties' enterprise was such that it would be impossible or not feasible to determine how much care that the reasonable person in the defendant's position would have taken. ${ }^{111}$ This last-mentioned approach was killed off by the decision in Gray. ${ }^{112}$ In turn, Hounga arguably cut from the law the causal approach that had been developed in Gray and replaced it with a policy test. The fact that the law of illegality has been changed so rapidly and frequently is highly objectionable. This is because it makes it impossible to predict with confidence what test will be applied at any given time.

An important question to consider in this regard is how the problem of uncertainty can be addressed without heightening the difficulties that arise on account of numerous and rapid changes in the law. Whereas a new articulation of the law of illegality might attend to the problem of uncertainty, such an articulation would involve yet another change to the law in this area. However, given the magnitude of the uncertainty that is



${ }^{105}$ Tinsley (n 25).

${ }^{106}$ See the text accompanying nn 29-30, above.

${ }^{107}$ See the text accompanying nn 24-26, above.

${ }^{108}$ See the text accompanying $n 28$, above.

${ }^{109}$ Lane $v$ Holloway [1968] 1 QB 379 (CA); Ashmore v Rock Steady Security Ltd 2006 SLT 207.

${ }^{110}$ Revill v Newberry [1996] QB 567 (CA). This test now prevails in Australia: see the cases mentioned in $\mathrm{n} 93$, above.

${ }^{111}$ Ashton v Turner [1981] QB 137 (QB); Pitts v Hunt [1991] 1 QB 24 (CA). The origins of this approach lie in a stream of Australian authority: Smith v Jenkins (1970) 119 CLR 397; Jackson $v$ Harrison (1977) 138 CLR 438. These Australian cases are addressed in Goudkamp (n 103).

${ }^{112}$ For discussion, see James Goudkamp, 'The Defence of Illegality in Tort Law: Wither the Rule in Pitts v Hunt?' (2012) 71 CLJ 481.
} 
widely acknowledged to afflict the illegality doctrine, it would seem that a further statement of the law in this regard would be the lesser of two evils, provided, of course, that it answers more questions about the doctrine than it raises.

A third rule-of-law challenge presented by the law of illegality concerns its inaccessibility. The jurisprudence in relation to the illegality doctrine is on a vast scale. A prodigious number of cases have addressed it, often at great length. ${ }^{113}$ The size of the law presents major challenges in terms of its accessibility. ${ }^{114}$ Laws that are inaccessible are just as problematic from a rule-of-law perspective as laws that are uncertain or frequently changing. It was noted at the start of this article that Lord Neuberger has indicated that the illegality doctrine should be considered by the Supreme Court sitting as a panel of seven or nine Justices as soon as it is reasonably appropriate to do so. ${ }^{115}$ With respect, in many ways, this is the opposite of how the Supreme Court should proceed. ${ }^{116}$ The greater the number of judges sitting, the longer and consequently more impenetrable the Court's reasons are likely to be. Another prolix judgment will simply further compromise the accessibility of the law concerning the illegality doctrine. Lord Neuberger apparently thought that an augmented panel should hear the next appeal that raises the illegality doctrine in order to prevent a differently constituted panel in a later case opting for different rules. However, the best way to address that problem arguably is not to convene a larger panel (which may do more harm than good) but to insist on stricter adherence to the time-honoured principle that once a rule has been established the by ultimate appellate court, a subsequent bench should not depart from it simply because they would have preferred it had a different rule been adopted.

\footnotetext{
${ }^{113}$ See the text accompanying nn 6-7, above, concerning the decision in Stone \& Rolls (n 6).

${ }^{114}$ Consider in this connection the penetrating remarks in Tom Bingham, The Rule of Law (Penguin Books, 2010) 42-46.

${ }^{115}$ See the text accompanying $\mathrm{n} 10$, above

${ }^{116}$ For illuminating discussion regarding the size of panels sitting in the Supreme Court, see Andrew Burrows, 'Numbers sitting in the Supreme Court' (2013) 129 LQR 305; Richard Buxton, 'Sitting en banc in the new Supreme Court' (2009) 125 LQR 288.
} 


\section{Conclusion}

The Supreme Court's jurisprudence in relation to the illegality doctrine bears a resemblance in certain ways to the case law produced by the High Court of Australia in relation to the duty of care concept around the start of the twenty-first century. ${ }^{117}$ At that period of time, the High Court delivered a succession of decisions regarding the duty of care. Many of these decisions were extraordinarily lengthy. ${ }^{118}$ Several of them were notable for the fact that all of the Justices who heard the appeal gave separate concurring opinions which differed markedly from each other in terms of their reasoning. ${ }^{119}$ The tremendous outpouring of effort left the law no clearer or stable. Indeed, it had the opposite effect. The High Court lurched from one test for the existence of a duty of care to another. A decisive moment in this saga was the decision in Sullivan $v$ Moody. ${ }^{120}$ In this case, the High Court spoke in a single set of reasons. ${ }^{121}$ The decision is brief. ${ }^{122}$ For all intents and purposes, it brought an end to the uncertainty and instability that had prevailed. Justice of the High Court who had previously taken very different views of the law recognised in subsequent cases that they were required to embrace the solution that had been endorsed in Sullivan. ${ }^{123}$ The law governing the illegality doctrine in the United Kingdom is waiting for its Sullivan moment.

${ }^{117}$ For excellent treatments of the High Court of Australia's duty of care jurisprudence, see Peter Cane, 'The Blight of Economic Loss: Is There Life after Perre v Apand?' (2000) 8 Torts LJ 246; Kit Barker, 'Economic Loss and the Duty of Care: a Study in the Exercise of Legal Justification' in Charles Rickett (ed), Justifying Private Law Remedies (Hart Publishing 2008).

${ }^{118}$ See e.g. Pyrenees Shire Council v Day [1998] HCA 3, (1998) 192 CLR 330 (258 paragraphs); Perre $v$ Apand Pty Ltd [1998] HCA 36, (1999) 198 CLR 180 (437 paragraphs); Crimmins v Stevedoring Committee [1999] HCA 59, (1999) 200 CLR 1 (370 paragraphs); Modbury Triangle Shopping Centre Pty Ltd v Anzil [2000] HCA 61, (2000) 205 CLR 254 (152 paragraphs); Tepko Pty Ltd $v$ Water Board [2001] HCA 19, (2001) 206 CLR 1 (172 paragraphs); Brodie v Singleton Shire Council [2001] HCA 29 (382 paragraphs).

${ }^{119}$ See e.g. Perre (n 118).

${ }^{120}$ [2001] HCA 59, (2001) 207 CLR 562.

${ }^{121}$ Gleeson CJ, Gaudron, McHugh, Hayne and Callinan JJ.

${ }^{122}$ It runs to a mere 66 paragraphs.

${ }^{123}$ See, in particular, the remarks of Kirby J in Graham Barclay Oysters Pty Ltd $v$ Ryan [2002] HCA 54, (1999) 211 CLR 520 [237]-[238]. 